\title{
Psychological Mechanisms of the Expression of Absurd Meaning in the Plays of W. Shakespeare
}

\section{Психологічні механізми вираження абсурдного смислу в творах В. Шекспіра}

Nataliia Mykhalchuk

Dr. in Psychology, Professor
Наталія Михальчук доктор психологічних наук, професор

E-mail: natasha1273@ukr.net orcid.org/0000-0003-0492-9450

Researcher ID: A-9440-2019

Rivne State University of the Humanities, Rivne, Ukraine

12, Stepan Bandera str., Rivne, 33000

\section{Iryna Koval}

Ph.D. in Psychology, Assistant Professor
Рівненський державний гуманітарний університет, м. Рівне, Україна вул. Степана Бандери, 12 , м. Рівне, 33000

\section{Ірина Коваль}

кандидат психологічних наук, доцент

E-mail:iryna-koval@i.ua orcid.org/0000-0002-2048-0000

Researcher ID: B-2173-2019

Khmelnytskyi National University, Khmelnytskyi, Ukraine

11, Instytutska str., Khmelnytskyi, 29016
Хмельницький національний університет, м. Хлельницький, Україна вул. Інститутська, 11, м. Хмельницький, 29016

Original manuscript received December 20, 2018 Revised manuscript accepted January 21, 2019 


\section{ABSTRACT}

The article deals with the definitions of the term "absurd», the paradigm of commedia dell'arte from a psychological point of view. It was shown that the role of the absurd in Shakespeare's plays was outlined. It was noted that the term "absurd" came from the Latin: "absurdus» is "nonsignificance», "nonsense». The absurdity, on the one hand, is connected with the "skepticism» of Socrates (I know that I do not know anything), and, on the other hand, with Socratic irony (do not isolate anything completed, finished, forever given and unchanged). It was noted that already in the ancient art the absurd was used to reach the understanding of unknown things and actions. In particular, in the anthology, pantomime, the clown appears as moros or stupidus; his absurd behavior is a result of his inability to understand the simplest logical connections of things.

It was stressed that thanked to the absurdity, W. Shakespeare opened new faces, new depths and, at the same time, the tragedy in Renaissance dualism. It was noted that the official status of the Person W. Shakespeare considered unreal, temporary; the negative characters in his drama were people who seek to conquer or strengthen their official status. Such a life goal is false, perverse, leads eventually to a vital defeat. In order to achieve their deceptive purpose, such people often have drown in natural feelings or sacrifice natural links, that is, in such a way, they are killing their natural essence.

Given the absurd frames, explicated in the plays of W. Shakespeare, the article highlights the psychological mechanisms of the expression of the absurd meaning by a writer. These are such mechanisms as: the explication of absurd frames existing in the consciousness of the individual; the images of absurd in terms of random details, archetypes, metaphorical contexts; the explication of the absurdly hidden nature of causal relationships that appear to be evident as a result of the usage of certain lexical units by the author, lexicalstylistic means, etc.; the presentation of a play of an absurd tie by the author; the presentation of the context of deciphering the play by the author with an absurdly displaced center.

The article emphasized that it was necessary to pay attention, first of all, to the fact that the understanding of the absurdity was arising as a result of unexpected for the reader transforming the tense context of the play into quite obvious semantic frames. According to such conditions, the witty absurdity will include the fact that the reader first perceives a play for the truth that misleads him, and then turns into persistent absurd frames that are fixed, fixed in the consciousness of the individual. Such frames, in turn, can be understood by the reader as containing nonsense, senselessness, can lead to the 
creation of stable cliches (built on the principle of "game of ideas»), which, in turn, become structural components of human consciousness.

Key words: absurd, commedia dell'arte, absurd frames, metaphorical contexts, psychological mechanisms of the expression of absurd meaning.

\section{Вступ}

Ми живемо у XXI столітті, проте сучасне суспільство нерідко нехтує моральними цінностями та правилами поведінки. Багато сучасників на перше місце ставлять матеріальні блага, а не духовне збагачення особистості. Утім, світова література пропонує велику кількість чудових творів, із яких ми можемо брати нові знання та отримувати естетичне задоволення. Чимало персонажів стають для нас взірцем для наслідування, а їхні вчинки навчають нас, як правильно жити та гуманно ставитися до інших.

Творчість англійського письменника Вільяма Шекспіра є для нас своєрідним яскравим прикладом, оскільки чим більш зрілим людство стає в духовному аспекті, тим більшою мірою воно відкриватиме глибини у творчості Шекспіра. Адже творчість В. Шекспіра - видатного гуманіста епохи пізнього Відродження - давно і заслужено здобула собі світову славу. Основну силу В. Шекспіра як безсмертного письменника, творця та натхненника для інших складає поєднання глибини і дохідливості, простоти і складності його творів. На різних етапах творчого шляху поета дійсність представлялась різними гранями і в різному осяянні. Невипадково геній В. Шекспіра найповніше виразився в драматургії, яка за самою своєю суттю більше за інші види мистецтва здатна передати драматизм життя. Уперше в світовій літературі В. Шекспір створив багатовимірні й естетично збагачені смислом людські характери. У його п’єсах змальовані живі люди, розкриті всі прояви людської натури.

Однак деякі питання в науковій літературі залишаються не до кінця розв'язаними. Зокрема, не зовсім детально проаналізовано роль абсурду в творчості В. Шекспіра, особливо на прикладах автентичних текстів. Актуальність 
дослідження зумовлена, по-перше, тим, що в роботі досліджується еволюція становлення англійської драми від античності до сучасності - жанру, розвиток якого збагатив художній арсенал усієї західноєвропейської літератури; по-друге, тим, що виявлення спільного між декількома літературними творами В. Шекспіра на рівні теми, ідеї, образів сприятиме формуванню шанобливого ставлення до духовних і матеріальних цінностей людства.

Також не розв'язаними в психологічній літературі є, зокрема, питання структури свідомості талановитої людини, її фреймової сутності, до якої, на наше переконання, мають входити, у тому числі, стійкі архетипові утворення, які фасилітуватимуть зміст свідомості особистості В. Шекспіра. Зокрема, до свідомості цього письменника повинні входити певні фрейми, які експлікують здатність до відтворення абсурду. Адже, якщо взяти до уваги теорію О. М. Шпортун (Шпортун, 2018), яка займалася питаннями психології та патопсихології гумору, то стає зрозуміло, що гумор великою мірою є генетично зумовленою якістю індивіда. Зокрема, не всі люди здатні до адекватного сприйняття гумору, деякі взагалі не сприймають гумор як такий, а абсурдистські тенденції їм не властиві та важкі за своїм смисловим навантаженням.

Термін «абсурд» походить від лат. absurdus - нісенітниця, безглуздя. Абсурд, з одного боку, пов'язаний зі «скептицизмом» Сократа (знаю те, що нічого не знаю), а з іншого - із сократівською іронією (не виокремлювати нічого завершеного, закінченого, назавжди даного i незмінного). Уже в античному мистецтві прийоми абсурду використовувалися для досягнення розуміння невідомих речей i дій. Зокрема, в античній виставі-пантомімі клоун з'являється як moros або stupidus; його абсурдна поведінка постає немовби результат його неспроможності зрозуміти найпростіші логічні зв'язки. Такі гротескні характери з'являються, передусім, у пантомімі за непродумано реалістичною угодою, але, що характерно, ці п’єси були час- 
то наполовину імпровізованими, завдяки чому персонажі мали змогу коригувати свою поведінку, власні риторичні виступи з метою досягнення повного розуміння зі сторони публіки (Сьювелл, 1952).

Цей напрямок у традиційному театрі зберігся впродовж Середньовіччя (коли освічені люди переписували комедії Плавта) завдяки мандрівним ioculatores i клоунам, які були прямими нащадками героїв римських пантомім. Ïx клоунада і блазнювання часто експлікувалося в комічних персонажах, таких як Диявол, у французьких і англійських п'єсах-містеріях, у численних французьких фарсах, у німецьких фастнахтшпілях.

Іншим нащадком античної пантоміми був придворний блазень. «Довга палиця, яку він носив, була дерев'яним мечем комічного героя в античні часи» (Стоквелл, 2002). I клоуни, і блазні з'являються як комічні персонажі у театрі В. Шекспіра. Розуміння в п’єсах В. Шекспіра досягається, у більшості випадків, використанням в абсолютно подібному вигляді перевернутих логічних міркувань, помилкових силогізмів, вільних асоціацій, а також поетикою реального чи удаваного божевілля, які ми пізніше знаходимо в п'єсах Е. Йонеско, С. Беккета та Г. Пінтера. Із вищезгаданого стає зрозуміло, що і фантастичне, i беззмістовно-абсурдне має доволі переконливу та загальноприйняту традицію впливати на спостерігача й передувати його розумінню.

Ці елементи у творчості В. Шекспіра є частиною цілого, відзначеного у поєднанні поетичного і літературного, популярного і народного. Якщо в шекспірівському традиційному театрі елементи народного, спонтанного i, в багатьох випадках, ірраціонального, народно-традиційного, експлікуються і в літературі, то традиція античної драми поза сферою літератури продовжується і знаходить своє відображення в Італії в commedia dell'arte як найвдаліша для розуміння їі всіма верствами населення. Незважаючи на те, що твердження В. Стівенса (Стівенс, 1968) щодо прямого взаємозв' язку між пантомімою та імпровізованою 
commedia dell'arte є помилковим, літературознавцями відзначається очевидність суттєвої подібності цих жанрів у плані досягнення усвідомлення та розуміння їх смислу, навіть якщо інформація подається у прихованому, завуальованому вигляді. Розуміння поєднує таку необхідну для людини потребу в блазнюванні, звільненні від заборон через спонтанний сміх. Багато традиційних лацці (Lazzi), вербальних і невербальних жартів commedia dell'arte пов'язані з пантомімами. Тут ми знову зустрічаємо недолугого простака, який не може зрозуміти значення найуживаніших термінів і плутається в безкінечних семантичних роздумах. Повторювальні типи хитрого слуги, хвалька, ненажери, простакуватого дивака, фальшивого вченого проектують основні рушійні сили людської самосвідомості в образах такими ж вдалими, якими потворними вони є насправді. У своїй основі цей простий театр значно залежить від професійної майстерності виконавців. Як зазначає Йозеф Грегор, «якщо ми уявимо собі ці самі по собі банальні мотиви, представлені в майже надлюдській плутанині, жарти, достатньо недоумкуваті, але поєднані з надлюдською спритністю, акробатів із надзвичайною майстерністю, ми зможемо осягнути та зрозуміти ідею цього театру» (Грегор, 1933).

Маніфест commedia dell'arte був настільки суттєвим у різних проявах, що зберігся до сьогоднішніх днів. У Франції він увійшов у парадигму легітимної драми через твори Мольєра. Але в частково літературних формах цей напрям наполегливо продовжував виявлятися в пантомімахfunambules. У Великій Британії традиції commedia dell'arte експлікувалися також і в арлекінаді аж до XIX століття, коли досягли вершини свого успіху в натхненній клоунаді Грімальді. Арлекінада заклала підвалини більш пізньої англійської пантоміми, яка в дещо видозміненій формі продовжує своє існування і в наш час як нестримний прояв правдиво вульгарного народного театру. Інші елементи арлекінади знайшли своє відображення в традиції англій- 
ського мюзик-холу й американського водевілю з його комедійними акторами, які перемовляються між собою, а розуміння досягається степом і комічними піснями.

Доба, в яку жив і творив В. Шекспір, отримала назву Ренесанс, або Відродження. Це було справжнім переворотом, унаслідок якого середньовічна система цінностей змінилася новим світоглядом. Цей світогляд мав суто антропоцентричний характер - уже людина, а не Бог, стала центром Всесвіту. Людина відкриває для себе безмежність і невичерпне багатство навколишнього світу, ідеалом стає всебічно розвинена, духовно досконала, гармонійна особистість. Світогляд тієї доби називають гуманістичним. За своєю суттю, названа вище ідеологія засновувалася на вірі в людину, в эï духовну й моральну природу, її необмежені можливості саморозвитку та самовдосконалення. Класичне формулювання світогляд доби Ренесансу знайшов у трактаті італійського гуманіста Піко делла Мірандоли «Про людську гідність» (1486), де автор, звертаючись до людини від імені Бога-творця, проголошував: «Я ставлю тебе в центр світу, щоб звідти було тобі зручніше бачити все, що є у світі». Піко делла Мірандола оспівував «дивне і високе призначення людини, яка може досягнути всього, до чого вона прагне, і бути тим, ким вона захоче», оскільки тільки людині «дана можливість впасти до тваринного рівня або піднятися до богоподібної істоти - винятково завдяки внутрішній волі». Вінцем цієї утопії, цього, так би мовити, епохального міфу самосвідомості культури Відродження була ідея досконалості людини в гармонійному світі. Середньовіччя недостатньою мірою цікавилося внутрішнім світом людини. Епоха Відродження поставила людину в центр уваги, письменники відкривали нові глибини iii внутрішнього світу. Звільнившись від світосприйняття Середньовіччя, згідно з яким людина була слухняною маріонеткою в руках Бога, вони зрозуміли величність людини.

До третього періоду творчості В. Шекспіра (1608-1612) належать трагікомедії «Перікл», «Цимбелін», «Зимова 
казка», «Буря», у яких виявляються поєднаними, скомпресованими фантастика й алегоризм. У останній період своєї творчості В. Шекспір залишається вірним ідеалам гуманізму, хоча ілюзій щодо гуманізму нового капіталістичного устрою в нього вже не було. Не знайшовши втілення в реальному житті, ідеали гуманізму в творчій фантазії В. Шекспіра набули форми мрії про майбутнє, про чудовий, казковий новий світ. Ця мрія, за умов відсутності можливості реалізації їі в дійсності, втілювалася у формі фантастичних елементів, пасторальних сцен і алегорій, характерних для творчості В. Шекспіра останнього періоду.

У драмах третього періоду В. Шекспір звертається до змішання фантастики з реальністю, до фольклорних мотивів, до казкових сюжетів і утопічних ситуацій, до мальовничих сцен, що розгортаються на тлі природи. У пізніх трагікомедіях В. Шекспіра панує лірико-героїчний початок, романтика виняткових подій. Цим п’єсам властива тематика протиставлення суспільства і природи, жорстоких придворних уподобань та ідеалістичного сільського життя. Однак, непогодження з мораллю суспільства є в цьому випадку формою морально-етичної критики такого суспільства, а не закликом бігти, втекти від нього. Не випадково, що герої повертаються в суспільство, щоб продовжувати боротьбу зі злом.

Важливою проблемою для В. Шекспіра $є$ проблема людського характеру. В центрі сюжету більшості драм письменника постає особистість, яка розкривається в боротьбі, що відбувається в сьогоденні (у своїх п’єсах В. Шекспір ніколи не описує передісторію своїх героїв). Проте в сучасному зарубіжному шекспірознавстві можна помітити нові намагання заперечити вплив гуманістичної філософії на світогляд і представити творчість великого драматурга лише продуктом середніх віків.

Саме у цей час філософське поняття «людина» підлягало значній зміні й розвитку, що, в свою чергу, призвело 

до відповідного розширення значення дефініції «людина», збагачення ㄲï ідейного змісту, зміни синонімічного ряду, втрати старих і нових співвідносних зв'язків з іншими словами та поняттями.

Активне використання слова «людина», зміна і збільшення лексичних засобів вираження позначуваного ним поняття, нове тлумачення і філософський зміст - усе це пов'язано з утвердженням нового ставлення до людини, характерного для світогляду провідних мислителів епохи Відродження, епохи гуманізму, коли утверджується нове розуміння людини, людської індивідуальності тощо.

В основу вживання фрейму «людина» в цьому контексті покладено уявлення про людину як істоту, наділену нескінченними здібностями, високими розумовими якостями та красою тіла. Саме в даному випадку «людина» вживається як філософсько-психологічний термін у повному розумінні цього слова.

Нове трактування та ставлення до терміна «людина» ми бачимо, зокрема, в «Гамлеті» (Шекспір, 1998). Ця дефініція стає ще більш переконливішою, коли навести такі середньовічні й антигуманістичні порівняння та епітети «людини», як комаха, залишок, нікчема, крихта. Отже, слово «людина» постає в «Гамлеті» як термінологічний експлікатор поняття «людина» i має експресивно завершене філософське значення. Так, В. Шекспір наповнює це слово новим гуманістичним змістом, продовжуючи кращі традиції класичної та гуманістичної філософії.

Мета статті - з урахуванням абсурдистських фреймів, експлікованих у творах В. Шекспіра, виокремити психологічні механізми вираження письменником абсурдного смислу •

\section{Завдання статті}

1. Проаналізувати сутність терміна «абсурд», парадигму commedia dell'arte з психологічної точки зору.

2. Окреслити роль абсурду в творах В. Шекспіра. 
3. Виокремити психологічні механізми вираження В. Шекспіром абсурдного смислу, актуалізувати значення цих механізмів для розуміння сенсу його творів.

\section{Методи дослідження}

У статті використано такі методи: цілісний психолінгвістичний, лінгво-культурологічний, проблемно-тематичний, порівняльний, зіставний, компаративний аналіз літературного твору тощо.

\section{Результати та дискусії}

Розуміння абсурду В. Шекспіром великою мірою зумовлюється тим, що думка Шекспіра ніби «розчинена» в образах і ситуаціях його п’єс, і саме завдяки цьому він зумів так повно, усебічно розкрити характери й обставини, що картини, створені автором, багаті та складні, як сама дійсність. Ось чому, коли пропонуються різні тлумачення п’єс В. Шекспіра, то вони так само - різноманітні, а часом і суперечливі, як і думки різних людей про оточуючу нас дійсність.

У міру того, як усе більше визнавалося в світі значення Шекспіра, кожне покоління по-новому осмислювало для себе його твори, по-новому тлумачило їх. Усе більшою мірою розкривалися глибокі думки, закладені В. Шекспіром у його п'єси, усе ясніше поставала його художня майстерність.

Художня система драматургії Шекспіра сформувалася, переважно, на грунті традицій народного театру, проте великою мірою зобов' язана спадщині античного театру. Драма класичної давнини відрізнялася суворою композицією побудови. У п’єсах античних авторів дія, як правило, відбувалася в одному місці й упродовж досить короткого періоду (близько доби); сюжет містив лише одну подію, що зображувалася без будь-яких відхилень. У трагедіях дія взагалі починалася вже напередодні розв'язки конфлікту. 
Завдяки презентації абсурду, абсурдистським тенденціям тощо творчість великого англійського письменника В. Шекспіра має всесвітнє значення. Шекспірівський геній дорогий усьому людству. Світ ідей і образів поетів-гуманістів узагалі є величезним, а всесвітнє значення В. Шекспіра полягає також у реалізмі й народності його творчості. Так, В. Шекспір розробив основні принципи ренесансної драматургії, його концепція драми сформувалася на базі складного синтезу ренесансної історіософії і старозавітної концепції щодо вільної особистості людини. Як ренесансний митець, драматург актуалізував вільну особистість людини і наголошував на її кінцевій перемозі над усім світом.

Водночас у його зображенні людина, прагнучи досягти своєї мети, постійно зіштовхується з протидією з боку інших людей, які зводять нанівець її вільну особистість. Ця протидія може бути абсурдно свідолою з боку іншої людини (так, у «Гамлеті» король Клавдій свідомо діє проти принца і заважає йому здійснити план помсти), але так само - i несвідомою (в комедіях, у «Ромео і Джульєтті» (Шекспір, 1997)). Тоді ми кажемо, що несвідома протидія уособлює роль абсурдної випадковості. Людина безсила проти випадковостей; вона може врахувати причинно-наслідкові зв'язки лише в безпосередній близькості від себе, але втручання віддалених сил, які руйнують її життя або вносять у нього хаос і сум'яття, вона передбачити не може.

У цьому абсурдно прихованолу характері причиннонаслідкових зв'язків полягає, за В. Шекспіром, непевність існування людини, що може стати навіть трагічною. Це відповідає старозавітній концепції втручання вищих, непізнаних сил у життя людини. Так, біблійний персонаж Авраам ретельно і дбайливо, крок за кроком будував свій добробут, але наслідок його праведного способу життя виявився для нього цілком непередбачуваним: Ягве зажадав від нього принести в жертву улюбленого сина Ісаака. Але й на цей раз наслідок був несподіваним, бо Ягве врятував 
Ісаака. 3 іншого боку, панування випадковості може стати причиною комічного безладдя (як, зокрема, у комедіях).

За своєю суттю, трагічне й абсурдне мають у Шекспіра єдину основу. В його комедіях, як правило, ми знаходимо серед комедійних колізій одну таку, де події розвиваються з драматичною гостротою («Багато галасу даремно», «Сон літньої ночі»); водночас досить часто у трагедіях мають місце комічні ситуації та комічні персонажі, а деякі трагедії до певного місця розвиваються за законами комедійної колізії («Ромео і Джульєтта»). Деякі трагедії написані на сюжети комічних італійських новел («Отелло»).

Отже, абсурд - це домінуючий пафос усієї доби Ренесансу, що виражає звільнення особистості. Через комічне людина внутрішньо емансипується від влади духовних догм, морального тиску тощо. Але, звільнившись від догми, тиску чи духовного ярма, людина опиняється перед складним завданням самостійно приймати рішення і нести тягар відповідальності, самостійно передбачати всі наслідки своїх дій. I тут виникає прагнення іншої людини до подібної духовної емансипації, нерідко - анархічно вільного утвердження власної волі. Ці окремі компоненти особистісної свободи внутрішньо емансипованих людей випадково зустрічаються, займають зовсім протилежні сторони і приходять до ситуації неминучого зіткнення. Від волі ренесансного автора великою мірою залежить, як експлікувати трагічне. Так, з одного й того самого матеріалу він може зробити і трагедію, і комедію, проте і в першому, і у другому випадках абсурд буде представлений у творі.

Концепція випадковостей i абсурдних прихованих причинно-наслідкових зв'язків відобразилася також на композиції п’єс Шекспіра. Драматург любить одночасно розгортати кілька сюжетних ліній, які «заважають» одна одній. На сцені, зрозуміло, ці лінії неможливо показати одночасно, тож В. Шекспір їх чергує і показує у вигляді невеликих фрагментів подій. Це створює ефект емоційної напруги й очікування. Але це вміщує також і світоглядний 
смисл. Нікому не дано вгадати наперед справжню логіку подій. Наслідок постійно віддаляється від нас, відокремлюється від своєї причини, ховається за випадковостями.

У В. Шекспіра в кожній п’єсі, незалежно від жанру, може бути від двох до п'яти і навіть більше сюжетних ліній. До сюжетних ліній повинні бути включені три компоненти: життєво важлива і конкретна мета, яку ставить перед собою персонаж; конкретні вчинки і дії, за допомогою яких він досягає своєї мети; конкретний наслідок цих вчинків і дій.

Особливо оригінально поєднує В. Шекспір сюжетні лінії в історичних драмах («хроніках»). Одна з них відтворює реальні історичні події, а інша - розгортає вигадані драматургом події суто особистісного, нерідко - інтимного життя персонажа. Розвиваючись відносно незалежно, ці лінії впливають одна на одну, визначають особливості особистого життя й історичної долі людини, виявляються примхливо пов'язаними між собою. Таким чином побудована історична драма «Генрі IV». Одна лінія відтворює реальну історичну подію - повстання графа Генрі Готспера проти короля, а інша знайомить нас із життям непутящого принца, спадкоємця престолу Генрі в товаристві шахраюватого i розпусного сера Джона Фальстафа (Генрі й Фальстаф нагадують нам іншу пару персонажів: Пантагрюеля і шахрая Панурга з книги Ф. Рабле).

Характерною особливістю Шекспірових драм є сюжетне дублювання з метою акцентування провідної думки твору. В цьому плані розкривається ідея невичерпності вибору, перед яким опиняється герой, або непередбачуваності подій, у яких життя розкривається перед людиною у своїй щедрій повноті. Так, акцентуючи вибір Гамлета-месника, драматург одночасно окреслює ще три лінії помсти: за своїх батьків мстять принц, Фортінбрас, син вельможі граф Лаерт і син грецького героя Ахілла - Пірр (персонаж із монологу актора). Кожен із чотирьох месників має свої, відмінні від інших, мотиви помсти, і всі вони діють по-різному. 
У п’єсі «Король Лір» лінія Ліра, зрадженого дочками, дублюється лінією батьківської драми графа Глостера, який вигнав люблячого сина Едгара і був підступно зраджений сином Едмундом. У «Ромео і Джульєтті» мотив кохання Ромео і Джульєтти контрастно відтінюється лініями Ромео - Розаліна і Парис - Джульєтта. У «Сні літньої ночі» презентовано шість пар закоханих (якщо враховувати також літературних персонажів Пірама і Тісбу); кожна пара по-своєму бореться за кохання, й у кожної доля складається по-своєму.

Структура драматичного сюжету у В. Шекспіра також є досить непростою, з огляду на практику перетину кількох сюжетних ліній. Нерідко автор застосовує абсурдну зав'язку; зокрема, в «Ромео і Джульєтті»- це сватання Париса до Джульєтти і згода дівчини. Одночасно ми дізнаємося про закоханість Ромео в Розаліну; отже, глядач готовий стежити за розвитком цих взаємостосунків. Проте справжня зав'язка відбувається лише наприкінці 1-ої дії; для цього драматург вводить дещо на зразок перипетії (бал у домі Капулетті, на якому обидві пари мають свідомий намір зустрітися), і вона завдає подіям зовсім іншого напрямку. Але якщо лінія Ромео - Розаліна «згортається» одразу після сцени балу, то лінія Парис - Джульєтта продовжує активно розвиватися і добігає свого завершення наприкінці п’єси, коли Парис гине біля склепу, захищаючи честь нареченої від зухвальця (Ромео). Отже, можна говорити про певну неоднозначність розв'язки, яка має такий собі «зміщений центр». Драматург прагне завершити розвиток усіх наведених сюжетних ліній приблизно в одній часовій і просторовій парадигмі.

Приклад абсурдної зав'язки ми також знаходимо в «Гамлеті», де появу привиду нічна варта і сам принц пов’язують спочатку з війною з Фортінбрасом. Істинний смисл нічної події розкривається лише в останній частині 1-ої дії, яку і можна вважати зав'язкою. Проте лінія Фортінбраса 
не зникає, більш того - появою Фортінбраса з армією завершується весь твір.

Непростою також є проблема кульмінацій у В. Шекспіра. Досить згадати «Отелло», де розв’язка - з абсурдно зліщенил иентрол (убивство Дездемони і смерть Отелло) призводить до складної смислової кульмінації. Так само не просто вказати на кульмінацію подій у «Ромео і Джульєтті»; адже тут трагічна смерть у склепі переходить у своєрідний апофеоз істини над тілами закоханих. У В. Шекспіра - прихильника міцної монархічної влади - значна кількість п'єс завершується урочистою сценою появи володаря, устами якого проголошується істина, справедливість, новий порядок. Можна стверджувати, що у В. Шекспіра катастрофа обов'язково переходить у катарсис, який також має абсурдну характеристику.

В основу всієї драматургічної проблематики В. Шекспіра покладено по-ренесансному осмислену ідею дуальності людини і світу. Ми знаємо, що античність спиралася на ідею цілісності світу і людини. Ідею роздвоєності і світу, і людини експлікувало християнство. Світ постає роздвоєним на теперішне - несправжнє і тимчасове, у якому фізично перебуває людина (сама по собі, до того ж, роздвоєна на тіло і душу), і майбутнє - справжнє і вічне, до якого людина прагне понад усе.

\section{Висновки}

Отже, в добу Відродження середньовічний дуалізм трансформувався у новий, ренесансний дуалізл. Ренесанс відкрив свою фундаментальну для європейської культури ідею иінності зелного життя, яке стає для людини справжнім, оскільки дає змогу знайти сенс у теперішньому. Але не було відкинуто повністю також ідею праведності й вічного життя. Так постали дві сторони людської особистості. Перша - це офіційний статус людини, тобто зафіксоване від народження місце у зовнішньому світі. Сюди входили: особистісна і майнова приналежності, васаль- 
на залежність, корпоративна чи партійна приналежність тощо. Друга сторона - це природна сутність людини, яка є також досить важливою, хоча вона і дарувалася безпосередньо Богом, але належала земному і виявлялася в земних справах. У цьому постає відмінність середньовічного розуміння душі, яка дарувалася Богом, але належала Богові, Богом же після смерті людини забиралася, а виявлялася на Землі в ділах віри. Так, ми можемо побачити у природній сутності людини її слислові переваги. Уперше тема природної сутності, або смислових переваг людини, була розроблена у Боккаччо. Він пов'язував цю сторону із земним коханням. Для закоханих існує одна цінність: людина сама по собі є чистою природною сутністю, що є незалежною від зовнішнього офіційного статусу. Персонажі більшості новел Боккаччо з легкістю відкидали цей офіційний статус як щось несуттєве для себе і діяли згідно з логікою власної природної сутності, тобто, згідно з логікою почуттів, життя серця.

Отже, завдяки абсурду В. Шекспір відкриває в ренесансному дуалізмі нові грані, нові глибини i, разом з тим, трагізм. Офіційний статус людини В. Шекспір вважав несправжнім, тимчасовим; негативні персонажі в його драмах - це люди, які прагнуть до завоювання чи зміцнення свого офіційного статусу. Така життєва мета - несправжня, облудна, призводить, зрештою, до життєвої поразки. Заради досягнення своєї облудної мети такі люди нерідко тамують у собі природні почуття чи жертвують природними зв' язками, тобто, вбивають свою природну сутність.

Справжньою стороною особистості В. Шекспір вважав ïi природну сутність. Трагізм він убачав у тому, що суспільство як таке засноване на офіційних відносинах між людьми й оцінює людину з погляду того, яке місце в суспільстві вона займає. Тільки інша, окремо взята людина

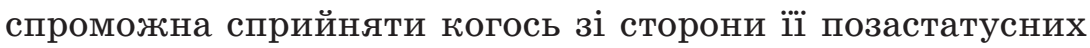
переваг, природної сутності. Шекспір розкриває трагічний конфлікт між консервативним суспільством і вільнолюб- 
ною особистістю. Суспільство хоче оцінювати людину з погляду одних законів, а вільнолюбна людина прагне жити за іншими, й абсурдна філософія ставлення до світу їй у цьому допомагає.

Отже, в тому числі завдяки абсурду, абсурдній грі слів В. Шекспір передав національний колорит англійської дійсності, характер англійської народної культури. Ніхто до нього не міг настільки колоритно за допомогою абсурдистських тенденцій зобразити хід самої історії, показати різні прошарки суспільства в єдиній динамічній системі. Також завдяки абсурду В. Шекспір зобразив у своїх творах переломний характер епохи, драматичну боротьбу між старим і новим. У його творах відобразився рух історії в їі трагічних протиріччях.

3 огляду на абсурдистські фрейми, експліковані у творах В. Шекспіра, нами були виокремлені психологічні механізми вираження абсурдного смислу письменником:

1) експлікація абсурдних фреймів, існуючих у свідомості особистості;

2) зображення абсурдних за змістом випадкових деталей, архетипів, метафоричних контекстів;

3) експлікація абсурдно прихованого характеру причинно-наслідкових зв'язків, що постають очевидними внаслідок вживання автором твору певних лексичних одиниць, лексико-стилістичних засобів тощо;

4) презентація автором твору абсурдної зав'язки;

5) презентація автором твору розв'язки твору з абсурдно зміщеним центром.

Отже, слід звернути увагу, передусім, на те, що розуміння абсурду виникає внаслідок неочікуваного читачем перетворення напруженого контексту твору у цілком очевидні смислові фрейми. За таких умов дотепний абсурд уміщуватиме те, що спочатку сприймається читачем твору як істина, що вводить його в оману, а потім перетворюється на стійкі абсурдистські фрейми, які закріплюються, фіксуються у свідомості особистості. Такі фрейми, у свою 
чергу, можуть розумітися читачем як такі, що вміщуватимуть нісенітницю, безглуздість, можуть призводити до створення стійких кліше (побудованих за принципом «гри ідей»), які згодом стають структурними компонентами свідомості людини.

\section{Література}

Шпортун О. М. Психологія та патопсихологія гумору: модель, діагностика, корекція : автореф. дис. ... д-ра психол. наук : 19.00.04. Київ : Ін-т психол. імені Г. С. Костюка НАПН України, 2018. 42 с. Gregor, J. (1933). Weltgeschichte des Theaters. Vienna : Mitteldeutscher Verlag. $308 \mathrm{~s}$.

Sewell, E. (1952). The Field of Nonsense. London : D. Campbell Publishers Ltd. $184 \mathrm{p}$.

Shakespeare, W. (1997). Romeo and Juliet. Cambridge : Mass. 189 p.

Shakespeare, W. (1998). Hamlet. Cambridge : Mass. 204 p.

Stephens, W. (1968). Hypotheses and Evridence. New York : Harper \& Row Publishers. $367 \mathrm{p}$.

Stockwell, P. (2002). Cognitive Poetics : An Intoduction. London, New York : Penguin Books. 193 p.

\section{References}

Shportun, O. M. (2018). Psykholohiia i patopsykholohiia humoru: model, diahnostyka, korektsiia [Psychology and pathopsychology of humor: the model, the diagnosis, correction]. Extended abstract of Doctor's thesis : 19.00.04]. Kyiv : In-t psykholohii im. H. S. Kostiuka NAN Ukrainy [in Ukrainian].

Gregor, J. (1933). Weltgeschichte des Theaters. Vienna : Mitteldeutscher Verlag. 308 s. [in German].

Sewell, E. (1952). The Field of Nonsense. London : D. Campbell Publishers Ltd. $184 \mathrm{p}$.

Shakespeare, W. (1997). Romeo and Juliet. Cambridge : Mass. 189 p.

Shakespeare, W. (1998). Hamlet. Cambridge : Mass. 204 p.

Stephens, W . (1968). Hypotheses and Evridence. New York : Harper \& Row Publishers. $367 \mathrm{p}$.

Stockwell, P. (2002). Cognitive Poetics : An Intoduction. London, New York : Penguin Books. 193 p.

\section{АНОТАЦІЯ}

У статті проаналізовано сутність терміна "абсурд», парадигму commedia dell'arte з психологічної точки зору. Окреслено роль абсурду в творах В. Шекспіра. Зазначено, що термін "абсурд» походить від лат. 

absurdus - нісенітниця, безглуздя. Абсурд, з одного боку, пов'язаний зі "скептицизмом» Сократа (знаю те, що нічого не знаю), а з іншого - із сократівською іронією (не виокремлювати нічого завершеного, закінченого, назавжди даного і незмінного). Зазначено, що вже в античному мистецтві прийоми абсурду використовувалися для досягнення розуміння невідомих речей і дій. Зокрема, в античній виставі-пантомімі клоун з'являється як moros або stupidus; його абсурдна поведінка постає немовби результат його неспроможності зрозуміти найпростіші логічні зв'язки.

Наголошено, що завдяки абсурду В. Шекспір відкриває в ренесансному дуалізмі нові грані, нові глибини і, разом з тим, - трагізм. Зазначено, що офріційний статус людини В. Шекспір вважав несправжнім, тимчасовим; негативні персонажі в його драмах - це люди, які прагнуть до завоювання чи зміцнення свого офріційного статусу. Така життєва мета несправжня, облудна і призводить, зрештою, до життєвої поразки. Заради досягнення своєї облудної мети такі люди нерідко тамують у собі природні почуття чи жертвують природними зв'язками, тобто вбивають свою природну сутність.

3 огляду на абсурдистські фрейми, експліковані у творах В. Шекспіра, виокремлено психологічні механізми вираження абсурдного смислу письменником. Це такі механізми, як: експлікація абсурдистських фреймів, існуючих у свідомості особистості; зображення абсурдних за змістом випадкових деталей, архетипів, метафоричних контекстів; експлікація абсурдно прихованого характеру причинно-наслідкових зв'язків, які постають очевидними внаслідок вживання автором твору певних лексичних одиниць, лексико-стилістичних засобів тощо; презентація автором твору абсурдної зав'язки; презентація автором твору розв'язки твору з абсурдно зміщеним центром.

у статті наголошено, що слід звернути увагу, передусім, на те, що розуміння абсурду виникає внаслідок неочікуваного читачем перетворення напруженого контексту твору в цілком очевидні смислові фрейми. За таких умов дотепний абсурд умішуватиме те, що спочатку сприймається читачем твору за істину, що вводить його в оману, а потім перетворюється на стійкі абсурдистські фрейми, які закріплюються, фіксуються у свідомості особистості. Такі фрейми, в свою чергу, можуть розумітися читачем як такі, що вміщуватимуть нісенітницю, безглуздість, можуть призводити до створення стійких кліше (побудованих за принципом «гри ідей»), які згодом стають структурними компонентами свідомості людини. 
Ключові слова: абсурд, commedia dell'arte, абсурдистські фрейми, метафоричні контексти, психологічні механізми вираження абсурдного смислу.

Михальчук Наталья, Коваль Ирина. Психологические механизмы выражения абсурдного смысла в произведениях В. Шекспира

\section{АННОТАЦИЯ}

В статье проанализированы сущность термина "абсурд», парадигма commedia dell'arte с психологической точки зрения. Определена роль абсурда в произведениях Шекспира. Указано, что термин "абсурд» происходит om лат. absurdus - бессмыслица, глупость. Абсурд, с одной стороны, связан с "скептицизмом» Сократа (знаю то, что ничего не знаю), а с другой - с сократовский иронией (не выделять ничего завершенного, законченного, навсегда данного и неизменного). Отмечено, что уже в античном искусстве приемы абсурда использовались для достижения понимания неизвестных вещей и действий. В частности, в античном спектакле-пантомиме клоун появляется как moros или stupidus; его абсурдное поведение возникает как результат его несостоятельности понять простейшие логические связи.

Отмечено, что благодаря абсурду В. Шекспир открывает в ренессансном дуализме новые грани, новые глубины и, вместе с тем, - трагизм. Отмечено, что официальный статус человека Шекспир считал ложным, временным; отрицательные персонажи в его драмах - это люди, которые стремятся к завоеванию или укреплению своего официального статуса. Такая жизненная цель - ложная, обманчивая и приводит, в конце концов, к жизненному поражению. Ради достижения своей лицемерной цели такие люди нередко заглушают в себе естественные чувства или жертвуют природными связями, то есть убивают свою природную сущность.

Учитывая абсурдистские фрреймы, которые эксплицированы в произведениях В. Шекспира, в статье выделены психологические механизмы выражения абсурдного смысла писателем. Это такие механизмы, как: экспликация абсурдистских фреймов, существующих в сознании личности; изображение абсурдных по содержанию случайных деталей, архетипов, метафорических контекстов; экспликация абсурдно скрытого характера причинно-следственных связей, которые являются очевидными в результате употребления автором произведения определенных лексических единии, лексико-стилистических средств; 
презентация автором произведения абсурдной завязки; презентация автором произведения развязки с абсурдно смещенным центром.

Отмечено, что следует обратить внимание, прежде всего, на то, что понимание абсурда возникает вследствие неожиданного преобразования читателем напряженного контекста произведения в совершенно очевидные смысловые фреймы. При таких условиях абсурд будет вмещать то, что сначала воспринимается читателем произведения за истину, что вводит его в заблуждение, а затем превращается в устойчивые абсурдистские фреймы, которые закрепляются, фиксируются в сознании личности. Такие фреймы, в свою очередь, могут пониматься читателем как такие, что будут включать чушь, нелепость, могут приводить к созданию устойчивых клише (построенных по принципу "игры идей»), которые вскоре становятся структурными компонентами сознания человека.

Ключевые слова: абсурд, commedia dell'arte, абсурдистские фреймы, метафорические контексты, психологические механизмы выражения абсурдного смысла. 